\title{
IMPLIKASI PENYALAHGUNAAN ALOKASI DANA DESA OLEH KEPALA DESA TERHADAP PEMERINTAHAN DESA
}

\author{
Oleh \\ Hasyim Adnan \\ hasyim_adnan17@yahoo.com
}

\begin{abstract}
The village fund allocation is part of the equalization funds received Kabupaten/Kota. The village fund allocation of at least 10\% of equalization funds received kabupaten/kota in budget income and Expenditure area (APBD) after deducting the funds allocation of special (DAK). The implementation of village financial management implemented by the village head, starting from the village chief delegate some authority to an appointed Councilor. The research methodology used is the juridical normative and descriptive research analytical. The village Fund Allocation abuse deeds was prohibited deeds performed by the village head. When done, then the head of the village is the administrative sanction in the form of an oral reprimand and/or a written reprimand. Such a feat is also a criminal offence of corruption, because of abusing authority which resulted in financial harm the State.
\end{abstract}

Keywords: Abuse, Dana Village, Village Chief

\begin{abstract}
Abstrak
Alokasi Dana Desa merupakan bagian dari dana perimbangan yang diterima Kabupaten/Kota. Alokasi Dana Desa tersebut paling sedikit 10\% (sepuluh perseratus) dari dana perimbangan yang diterima kabupaten/kota dalam Anggaran Pendapatan dan Belanja Daerah (APBD) setelah dikurangi Dana Alokasi Khusus (DAK). Pelaksanaan pengelolaan keuangan desa dilaksanakan oleh Kepala Desa, dimulai dari Kepala Desa melimpahkan sebagian kewenangan kepada Perangkat Desa yang ditunjuk. Metodologi penelitian yang digunakan merupakan penelitian yuridis normatif dan deskriptif analitis. Perbuatan penyalahgunaan Alokasi Dana Desa merupakan perbuatan yang dilarang dilakukan oleh Kepala Desa. Apabila dilakukan, maka Kepala Desa dikenai sanksi administratif berupa teguran lisan dan/atau teguran tertulis. Perbuatan tersebut juga merupakan tindak pidana korupsi, karena menyalahgunakan wewenangnya yang berakibat merugikan keuangan negara.
\end{abstract}

Kata kunci: Penyalahgunaan, Dana Desa, Kepala Desa. 


\section{PENDAHULUAN}

Sistem Pemerintahan Daerah di Indonesia menurut Konstitusi UndangUndang Dasar (UUD) 1945, dinyatakan bahwa Negara Kesatuan Republik Indonesia (NKRI) dibagi atas daerahdaerah Provinsi dan daerah Provinsi itu dibagi atas Kabupaten dan Kota, yang tiaptiap Provinsi, Kabupaten, dan Kota itu mempunyai Pemerintahan Daerah, yang diatur dengan Undang-Undang. ${ }^{1}$ Kemudian daerah-daerah yang bersifat otonom atau bersifat daerah administrasi, semuanya akan ditetapkan dengan Undang-undang. ${ }^{2}$

Desa dan Kelurahan merupakan satuan pemerintahan terendah dibawah Pemerintah Kabupaten/Kota. Desa dan Kelurahan adalah dua satuan pemerintahan terendah dengan status berbeda. Desa adalah satuan pemerintahan yang diberi hak otonomi adat sehingga merupakan badan hukum, sedangkan Kelurahan adalah satuan pemerintahan administrasi yang hanya merupakan kepanjangan tangan dari Pemerintah Kabupaten/Kota. Jadi, Kelurahan bukan badan hukum melainkan hanya sebagai tempat beroperasinya pelayanan pemerintahan dari Pemerintah Kabupaten/Kota di wilayah Kelurahan setempat. Sedangkan Desa adalah wilayah dengan batas-batas tertentu sebagai

\footnotetext{
${ }^{1}$ Pasal 18 ayat (1) UUD 1945

${ }^{2}$ Siswanto Sunarno, Hukum Pemerintahan Daerah di Indonesia, Sinar Grafika, Jakarta, 2008, hlm. 1.
}

kesatuan masyarakat hukum (adat) yang berhak mengatur dan mengurus urusan masyarakat setempat berdasarkan asalusulnya. $^{3}$

Desa atau yang disebut dengan nama lain telah ada sebelum Negara Kesatuan Republik Indonesia terbentuk. Sebagai bukti keberadaanya, Penjelasan Pasal 18 UUD 1945 (sebelum perubahan) menyebutkan bahwa "Dalam teritori Negara Indonesia terdapat lebih kurang 250 "Zelfbesturende landschappen" dan "Volksgemeenschappen", seperti desa di Jawa dan Bali, Nagari di Minangkabau, dusun dan marga di Palembang, dan sebagainya. Daerah-daerah itu mempunyai susunan Asli dan oleh karenanya dapat dianggap sebagai daerah yang bersifat istimewa. Negara Republik Indonesia menghormati kedudukan daerah-daerah istimewa tersebut dan segala peraturan negara yang mengenai daerah-daerah itu akan mengingati hak-hak asal-usul daerah tersebut. Oleh sebab itu, keberadaannya wajib diakui dan diberikan jaminan keberlangsungan hidupnya dalam Negara Kesatuan Republik Indonesia. ${ }^{4}$

Keberagaman karakteristik dan jenis Desa, atau yang disebut dengan nama lain, tidak menjadi penghalang bagi para pendiri bangsa (founding fathers) ini untuk

\footnotetext{
${ }^{3}$ Hanif Nurcholis, Pertumbuhan \& Penyelenggaraan Pemerintahan Desa, Erlangga, Jakarta, 2011, hlm. 1

${ }^{4}$ Penjelasan UU Nomor 6 Tahun 2014 tentang Desa
} 
menjatuhkan pilihannya pada bentuk negara kesatuan. Meskipun disadari bahwa dalam suatu negara kesatuan perlu terdapat homogenitas, tetapi Negara Kesatuan Republik Indonesia tetap memberikan pengakuan dan jaminan terhadap keberadaan kesatuan masyarakat hukum dan kesatuan masyarakat hukum adat beserta hak tradisionalnya. ${ }^{5}$

Berkaitan dengan susunan dan penyelenggaraan Pemerintahan Daerah, setelah perubahan UUD 1945, pengaturan desa atau disebut dengan nama lain dari segi pemerintahnnya mengacu pada ketentuan Pasal 18 ayat (7) UUD 1945, yang menegaskan bahwa "Susunan dan tata cara penyelenggaraan Pemerintahan Daerah diatur dalam undang-undang”. Hal itu berarti bahwa Pasal 18 ayat (7) UUD 1945 membuka kemungkinan adanya susunan pemerintahan dalam sistem pemerintahan Indonesia. ${ }^{6}$

Pertumbuhan Desa dimulai dari bentuk self-governing community diformalkan oleh Pemerintah Kolonial Belanda sebagai kesatuan masyarakat hukum atau inlandsche gemeenten, kemudian berkembang sebagai kesatuan masyarakat hukum adat. Sebagai kesatuan masyarakat hukum adat, Desa mempunyai lembaga-lembaga politik, ekonomi peradilan, sosial budaya, dan hankam yang dikembangkan sendiri untuk memenuhi kebutuhan hidupnya, baik lahir maupun batin. Kemudian untuk menunjang kelangsungan hidup kesatuan masyarakat hukum tersebut, Desa mempunyai kekayaan yang diatur sesuai dengan sistem kelembagaan yang dikembangkan sendiri, yaitu mempunyai wilayah yang hanya masyarakat Desa yang bersangkutan boleh mengatur dan mengurus urusannya. Orangorang luar yang tidak berkepentingan, tidak boleh ikut campur mengatur dan mengurus kepentingan masyarakat Desa yang bersangkutan. Kewenangan untuk mengatur dan mengurus rumah tangganya sendiri tersebut disebut otonomi Desa. ${ }^{7}$

Otonomi adalah subsistem dari Negara Kesatuan. Otonomi adalah fenomena Negara Kesatuan. Segala pengertian (begrip) dan isi (materie) otonomi adalah pengertian dan isi Negara Kesatuan. Negara Kesatuan merupakan landas batas dari pengertian dan isi otonomi. ${ }^{8}$

Selanjutnya nasib Desa pernah dicantumkan sebagai tingkat terendah daerah otonom, dalam Undang-Undang Nomor 5 Tahun 1974 tentang Pemerintahan Daerah hanya disebutkan dalam satu pasal, yaitu Pasal 88 yang

\footnotetext{
${ }^{7}$ Ibid, hlm. 19.

8 Bagir Manan, Perjalanan Historis Pasal 18 UUD 1945, Unsika, Karawang, 1993, hlm. 2 Dikutip dari Ridwan, Hukum Administrasi di Daerah, FH-UII, Yogyakarta, 2009, hlm. 14.
} 
menyatakan pengaturan pemerintahan

Desa ditetapkan dengan Undang-Undang. Kemudian pada tahun 1979 baru direalisasikan dengan dibuatnya UndangUndang Nomor 5 Tahun 1979 tentang Pemerintahan Desa. ${ }^{9}$

Pembangunan bersifat diskriminatif terhadap wilayah Desa, setidaknya dalam satu dekade terakhir. ${ }^{10}$ Diskriminasi terhadap desa pada berbagai bidang pembangunan berkonsekuensi pada ketertinggalan wilayah perdesaan. Pada tahun 2014 hanya terdapat 3,92 persen yang tergolong desa mandiri, sementara yang tergolong desa tertinggal sebanyak 27,22 persen, dan yang tergolong desa berkembang sebanyak 68,86 persen. ${ }^{11}$

Sesuai dengan Undang-Undang Nomor 6 Tahun 2014 tentang Desa, perubahan terhadap Pemerintah Desa seharusnya mencakup aspek penyelenggaraan Pemerintahan Desa dan pelaksanaan Pembangunan Desa. ${ }^{12}$

\footnotetext{
${ }^{9}$ Moh. Mahfud, Politik Hukum di Indonesia, Rajawali Press, Jakarta, 2010, hlm. 272.

${ }^{10}$ Nata Irawan, Tata Kelola Pemerintahan Desa Era UU Desa, Yayasan Pustaka Obor Indonesia, Jakarta, 2007, hlm.

11 Indeks Pembangunan Desa (IPD) yang disusun Bappenas dan BPS (2014) didasarkan pada komponen UndangUndang Nomor 6 Tahun 2014 tentang Desa yang tersedia pada data Potensi Desa 2014, mencakup komponen pelayanan dasar, kondisi infrastruktur, aksesibilitas/transportasi, pelayanan umum, dan penyelenggaraan pemerintahan. Komponen tersebut lebih sesuai dengan Undang-Undang Nomor 6 Tahun 2014 tentang Desa dibandingkan Indeks Desa Membangun (IDM) yang disusun Kementerian Desa, Pembangunan Daerah Tertinggal dan Transmigrasi (2014) berbasis data yang sama Potensi Desa 2014, dan mencakup komponen social, ekonomi dan ekologi, cakupan IDM tidak menampung aspek pemerintahan Desa. Dikutip dari Nata Irawan, Ibid.,

${ }^{12}$ Pasal 2 Undang-Undang Nomor 6 Tahun 2104 tentang Desa.
}

Desa secara administratif merupakan bentuk pemerintahan terkecil yang dipimpin oleh Kepala Desa dari sebuah pemilihan secara langsung. Secara formal Pemerintah telah menerbitkan Peraturan Pemerintah Nomor 72 Tahun 2005 tentang Desa sebagai dasar hukum yang mengatur dan dianggap penting tentang Desa.

Sebagai bentuk pemerintahan pada tingkat terbawah, Aparatur Desa (Kepala Desa dan Perangkat Desa) merupakan ujung tombak dalam pengurusan segala sesuatu yang sifatnya keadministrasian oleh masyarakat, dan untuk melaksanakan tugas dan urusan pemerintahan Desa tersebut, maka diperlukan dukungan sumber daya, baik personil, dana, maupun peralatan/perangkat penunjang lainnya. PP Nomor 72 Tahun 2005 tersebut mengatur sumber pembiayaan bagi desa dalam rangka memberikan pelayanan pada masyarakat antara lain dari sumber-sumber pendapatan asli Desa, adanya kewajiban bagi pemerintah dari pusat sampai dengan Kabupaten/Kota untuk memberikan transfer dana bagi Desa, hibah ataupun donasi.

Undang-Undang Nomor 6 Tahun 2014 tentang Desa Pasal 72 ayat (1) huruf d, mengatur tentang Pendapatan Desa bersumber dari alokasi dana Desa yang merupakan bagian dari dana perimbangan yang diterima Kabupaten/Kota, dan Pasal 
72 ayat (4), bahwa alokasi dana Desa paling sedikit $10 \%$ (sepuluh perseratus) dari dana perimbangan yang diterima Kabupaten/Kota dalam Anggaran Pendapatan dan Belanja daerah setelah dikurangi Dana Alokasi Khusus.

Perkembangan terbaru dalam Pemerintahan Desa sekarang ini, ada Kepala Desa dan Perangkat Desa sebagai Aparatur Desa dalam mengelola Alokasi Dana Desa itu tidak menjalankan aturan yang sudah ditetapkan dalam peraturan perundang-undangan tentang Desa.

Berdasarkan latar belakang tersebut, maka identifikasi masalahnya adalah bagaimana akibat penyalahgunaan Alokasi Dana Desa (ADD) oleh Kepala Desa.

Metode penelitian yang digunakan adalah metode yuridis normatif dan metode deskriptif analitis. Metode yuridis normatif adalah pendekatan yang dilakukan berdasarkan bahan hukum utama dengan cara menelaah teori-teori, konsep-konsep, asas-asas hukum serta peraturan perundang-undangan yang berhubungan dengan penelitian ini. Metode deskriptif analitis sebagai prosedur pemecahan masalah yang diselidiki dengan menggambarkan keadaan subyek atau obyek dalam penelitian dapat berupa orang, lembaga, masyarakat dan yang lainnya pada saat sekarang berdasarkan fakta-fakta yang tampak atau apa adanya.

\section{RUMUSAN MASALAH}

Bagaimana implikasi penyalahgunaan alokasi dana desa oleh kepala desa terhadap pemerintahan desa.

\section{TUJUAN PENELITIAN}

Untuk mengetahui implikasi penyalahgunaan alokasi dana desa oleh kepala desa terhadap pemerintahan desa.

\section{METODE PENELITIAN}

Metode penelitian yang digunakan metode penelitian yuridis normatif, metode pendekatan perundang-undangan, dan juga teknik analisis data.

\section{PEMBAHASAN}

Menurut sejarahnya, Desa merupakan cikal-bakal dari negara, dan keberadaannya yang jauh mendahului pembentukan negara. Desa juga dapat dijadikan struktur dasar organisasi negara. Desa sebagai suatu organisasi kekuasaan, struktur Pemerintah Desa berpusat pada Kepala Desa yang dibantu oleh Perangkat Desa.

Peraturan perundang-undangan Negara Republik Indonesia yang pertama kali secara khusus mengatur mengenai Pemerintahan Desa secara lengkap adalah 
Undang-Undang Nomor 5 Tahun 1979:

"Desa adalah suatu wilayah yang ditempati oleh sejumlah penduduk sebagai kesatuan masyarakat, termasuk didalamnya kesatuan masyarakat hukum, yang mempunyai organisasi pemerintahan terendah langsung di bawah Camat dan berhak menyelenggarakan rumah tangganya sendiri dalam ikatan Negara Kesatuan Republik Indonesia".

Pelaksanaan pengaturan Desa yang selama ini berlaku, sudah tidak sesuai lagi dengan perkembangan zaman, terutama berhubungan dengan kedudukan masyarakat hukum adat, demokratisasi, keberagaman, partisipasi masyarakat, serta kemajuan dan pemerataan pembangunan sehingga menimbulkan kesenjangan antar wilayah, kemiskinan, dan masalah sosial budaya yang dapat mengganggu keutuhan Negara Kesatuan Republik Indonesia (NKRI).

Pada tahun 2014 peraturan perundangundangan tentang Desa diundangkan, Undang-Undang Nomor 6 Tahun 2014 tentang Desa, kemudian ada Peraturan Pemerintah Nomor 43 Tahun 2014 tentang peraturan Pelaksanaan Undang-Undang Nomor 6 Tahun 2014 tentang Desa dan Peraturan Pemerintah Nomor 60 Tahun 2014 tentang Dana Desa yang Bersumber dari Anggaran Pendapatan dan Belanja Negara. Kemudian terjadi perubahan, dengan diberlakukannya Peraturan Pemerintah Nomor 47 Tahun 2015 tentang
Perubahan Atas Peraturan Pemerintah Nomor 43 Tahun 2014 tentang Peraturan Pelaksanaan Undang-Undang Nomor 6 Tahun 2014 tentang Desa. Selanjutnya diberlakukan juga Peraturan Pemerintah Nomor 22 Tahun 2015 tentang Perubahan Atas Peraturan Pemerintah Nomor 22 Tahun 2015 tentang Perubahan Atas Peraturan Pemerintahan Nomor 60 Tahun 2014 tentang Dana Desa yang Bersumber dari Anggaran Pendapatan dan Belanja Negara dan terjadi perubahan kembali dengan diberlakukannya Peraturan Pemerintah Nomor 8 Tahun 2016.

Desa adalah Desa dan Desa Adat atau yang disebut dengan nama lain, selanjutnya disebut Desa, adalah kesatuan masyarakat hukum yang memiliki batas wilayah yang berwenang untuk mengatur dan mengutus urusan pemerintahan, kepentingan masyarakat setempat berdasarkan prakarsa masyarakat, hak asalusul, dan/atau hak tradisional yang diakui dan dihormati dalam sistem pemerintahan Negara Kesatuan Republik Indonesia. ${ }^{13}$

Ada tiga macam penafsiran atau pengertian tentang desa: ${ }^{14}$

Pertama, pengertian secara sosiologis, yang menggambarkan suatu bentuk kesatuan masyarakat

\footnotetext{
${ }^{13}$ Pasal 1 butir (1) UU Nomor 6 Tahun 2014 tentang Desa.

14 Mashuri Maschab, Politik Pemerintahan Desa di Indonesia, PolGov UGM, Yogyakarta, 2013, hlm. 1-2.
} 
atau komunitas penduduk yang tinggal dan menetap dalam suatu lingkungan, dimana diantara mereka saling mengenal dengan baik dan corak kehidupan mereka relatif homogen, serta banyak bergantung kepada kebaikankebaikan alam. Menurut pengertian sosiologis tersebut, Desa diasosiasikan dengan suatu masyarakat yang hidup secara sederhana, pada umumnya hidup dari sektor pertanian, memiliki ikatan sosial dan adat atau tradisi yang masih kuat, sifatnya jujur dan bersahaja, pendidikannya relatif rendah dan lain sebagainya.

Kedua, pengertian secara ekonomi, Desa sebagai suatu lingkungan masyarakat yang berusaha memenuhi kebutuhan hidupnya sehari-hari dari apa yang disediakan alam di sekitarnya. Menurut pengertian secara ekonomi, desa merupakan satu lingkungan ekonomi, dimana penduduknya berusaha untuk memenuhi kebutuhan hidupnya. Sumber daya alam yang mereka miliki sangat besar berupa tanah pertanian, hutan, danau, laut dalam batas tertentu bisa memenuhi kebutuhan mereka untuk bertahan hidup (survival). Aktivitas-aktivitas seperti bertani, berburu, dan merambah hutan, menangkap ikan, beternak, menenun pakaian, dan anyaman-anyaman lainnya merupakan bagian dari usaha mereka membangun kehidupan. Batas-batas dalam aktivitas ekonomi ini kemudian diklaim menjadi hak milik desa. Pihak lain tidak boleh menggunakan, mengambil hasil, apalagi mengambil alih segala sesuatu yang dianggap hak milik mereka, tanpa ijin atau persetujuan warga Desa. Hubungan ekonomi atau perdagangan dengan pihak lain dalam sistem perekonomian subsistence ini sering dilakukan secara barter (tukar menukar barang) yang saling dibutuhkan.

Ketiga, pengertian secara politik, desa sebagai suatu organisasi pemerintahan atau organisasi kekuasaan yang secara politis mempunyai wewenang tertentu, karena merupakan bagian dari Pemerintahan Negara. Menurut pengertian secara politik, desa ditulis dengan huruf awal $\mathrm{d}$ besar ("Desa"). Desa sering dirumuskan sebagai "suatu kesatuan masyarakat hukum yang berkuasa 
menyelenggarakan pemerintahan sendiri”. Sebagai suatu kesatuan masyarakat hukum, maka Desa mempunyai kewenangan dalam lingkungan wilayahnya untuk mengatur dan memutuskan sesuatu sesuai dengan kepentingan masyarakat hukum yang bersangkutan. Oleh sebab itu, untuk membuat kewenangan tersebut absah atau legitimate, pemerintah pusat mengaturnya dalam undangundang.

Desa sebagai unit pemerintahan terkecil, dalam batas-batas tertentu dapat dipandang sebagai miniatur Negara. Desa dari segi unsur-unsurnya, secara mendasar Desa itu berbeda dengan Negara karena tidak memiliki kedaulatan. Desa dalam susunannya yang asli, sebelum diusik oleh Pemerintah Kolonial atau mengikuti format negara modern seperti sekarang ini; fungsi-fungsi legislatif, eksekutif, maupun yudikatif dapat dijalankan oleh struktur yang ada di Desa meskipun sangat sederhana, karena kebutuhan pemerintahan di Desa lebih sederhana. Meskipun demikian, terdapat kesejajaran dalam pengelolaan rumah tangga negara dengan rumah tangga Desa. Oleh sebab itu, mempelajari pemerintahan Desa adalah salah satu cara mendapatkan pemahaman mengenai jalannya negara dalam lingkup mikro. $^{15}$

Permasalahan Pemerintahan Desa di Indonesia bukanlah masalah yang bersifat mikro semata, walaupun Desa dapat diibaratkan dengan sel dalam suatu organisme. Keadaan Desa sangat berbeda antara satu Desa di suatu daerah dengan Desa di daerah lain. Perbedaannya tidak hanya bersifat semantik, yang tercermin dari keaneka-ragaman sebutan terhadap unit pemerintahan terkecil itu. Keanekaragaman tersebut meliputi juga susunan organisasi, tata cara kerjanya dan unjuk kerjanya. Sebetulnya sebutan Desa terhadap semua unit pemerintahan terkecil atau terendah di Indonesia adalah penyederhanaan yang berlebihan demi memudahkan pengendalian dan pembinaan. Penanganan terhadap Desa yang sangat beragam itu pada gilirannya menuntut suatu pola yang bersifat komprehensif, tetapi fleksibel dalam rangka menggalang potensi dan upaya melaksanakan pembangunan nasional. Jelasnya, dalam konteks nasional, permasalahan Pemerintahan Desa adalah permasalahan yang bersifat makro. Sehingga dalam kondisi demikian itu, terlihat adanya relevansi mempelajari Pemerintahan Desa sebagai suatu sistem yang terkait langsung dengan tatanan Negara Kesatuan Republk Indonesia

\footnotetext{
${ }^{15}$ Mashuri Maschab, ibid., hlm. 8.
} 
$(\mathrm{NKRI}) .{ }^{16}$

Mengenai pengertian atau apa yang dimengerti sebagai Desa itu sendiri, sampai sekarang belum ada keseragaman pendapat di kalangan para sarjana. ${ }^{17}$ Menurut Soetardjo Kartohadikoesoemo, Desa merupakan suatu kesatuan hukum, dimana bertempat tinggal suatu masyarakat yang berkuasa mengadakan pemerintahan sendiri. ${ }^{18}$ Sementara itu, menurut Hazairin, Desa di Jawa dan Madura, nagari di Minangkabau merupakan masyarakat hukum adat adalah kesatuan-kesatuan kemasyarakatan yang memiliki kelengkapan-kelengkapan untuk sanggup berdiri sendiri, yaitu memiliki kesatuan hukum, kesatuan penguasa, dan kesatuan lingkungan hidup berdasarkan hak bersama atas tanah dan air bagi semua anggotanya. $^{19}$

Desa menjadi tumpuan dan sekaligus sasaran pembangunan nasional. Mengingat saat ini mayoritas penduduk Indonesia masih tinggal di pedesaan, maka pemahaman tentang proses pembangunan di Desa merupakan hal yang sangat diperlukan, terlebih dalam konsep pembangunan yang partisipatif. Kondisi Indonesia dalam hal pembangunan

\footnotetext{
${ }^{16}$ Ibid., hlm. 8-9.

${ }^{17}$ Jimly Asshiddiqie, Pokok-Pokok Hukum Tata Negara Indonesia Pasca Reformasi, PT. Bhuana Ilmu Populer, Jakarta, 2007, hlm. 493.

18 Soetardjo Kartohadikoesoemo, Desa, UGM, Yogyakarta, 1953, hlm. 2.

${ }^{19}$ Hazairin, Demokrasi Pancasila, Tintamas, Jakarta, 1970, hlm.44.
}

tergantung atau didominasi oleh pemerintah, maka pembahasan mengenai Pemerintahan Desa menjadi sangat krusial. Studi tentang Desa menjadi sangat penting, mengingat bahwa sebagian besar wilayah negara merupakan wilayah Desa yang jumlahnya puluhan ribu dengan segala tradisi masyarakat dan ciri khasnya masing-masing. Selain itu, di desa-desa itu terletak jutaan hektar hutan, lahan gambut, hamparan lahan pertanian, danau, pantai, lembah dan bukit, bahkan gunung yang sebagian diantaranya mengandung berbagai sumber daya alam, gas, minyak dan berbagai jenis mineral, yang dalam pandangan warga Desa diyakini sebagai milik Desa warisan leluhur mereka. Seiring dengan makin kuatnya posisi Negara sehingga menempatkan Desa sebagai subsistem yang terkecil dan terendah dalam struktur Pemerintahan Negara, maka pengabaian atas hak-hak bahkan tata-nilai Desa semakin sering terjadi. Akibatnya maka sering terjadi konflik antara Desa dengan pihak luar (Pemerintah Pusat maupun Pengusaha) memperebutkan sumber daya Desa. ${ }^{20}$

Menurut Peraturan Menteri Dalam Negeri Nomor 56 Tahun 2015 tentang Kode dan Data Wilayah Administrasi Pemerintahan disebutkan bahwa jumlah Desa dan Kelurahan di Indonesia adalah

\footnotetext{
${ }^{20}$ Ibid.,
} 


\section{$83.184 \quad \mathbf{( 7 4 . 7 5 4}$ Desa dan 8.430}

Kelurahan).

Pemerintah

Kabupaten/Kota

mengalokasikan dalam Anggaran

Pendapatan dan Belanja Daerah setelah dikurangi Dana Alokasi Khusus. ${ }^{21}$ Kepala

Desa dalam rangka pengelolaan keuangan

Desa, melimpahkan sebagian kewenangan kepada perangkat Desa yang ditunjuk.

Selanjutnya, apabila Kabupaten/Kota tidak memberikan Alokasi Dana Desa, maka Pemerintah dapat melakukan penundaan dan/atau pemotongan sebesar alokasi dana perimbangan setelah dikurangi Dana Alokasi Khusus.

Alokasi Dana Desa dibagikan kepada setiap Desa dengan mempertimbangkan:

a. Kebutuhan penghasilan tetap Kepala Desa dan Perangkat Desa; dan

b. Jumlah penduduk Desa, angka kemiskinan Desa, luas wilayah Desa, dan tingkat kesulitan geografis Desa.

Salah satu sumber pendapatan Desa adalah Alokasi Dana Desa yang merupakan bagian dari dana perimbangan yang diterima Kabupaten/Kota. Alokasi Dana Desa tersebut paling sedikit $10 \%$

21 UU Nomor 33 Tahun 2004 tentang PerimbanganKeuangan Antara Pemerintah Pusat dan Pemerintahan Daerah, Dana Alokasi Khusus (DAK) adalah alokasi dari Anggaran Pendapatan dan Belanja Negara kepada Provinsi/Kabupaten/Kota tertentu dengan tujuan untuk mendanai kegiatan khusus yang merupakan urusan Pemerintahan Daerah dan sesuai dengan prioritas nasional. (sepuluh perseratus) dari dana perimbangan yang diterima Kabupaten/Kota dalam Anggaran Pendapatan dan Belanja Daerah setelah dikurangi Dana Alokasi Khusus. Kemudian dalam rangka pengelolaan keuangan Desa, Kepala Desa melimpahkan sebagian kewenangan kepada Perangkat Desa yang ditunjuk.

Perangkat Desa terdiri atas: (a) Sekretariat Desa; (b) Pelaksana Kewilayahan; (c) Pelaksana Teknis. Perangkat Desa bertugas membantu Kepala Desa dalam melaksanakan tugas dan wewenangnya, Perangkat Desa bertanggung jawab kepada Kepala Desa.

Pemerintah Kabupaten/Kota harus mengalokasikan dana dari Anggaran Pendapatan dan Belanja Daerahnya kepada Desa. Alokasi Dana Desa berasal dari APBD Kabupaten/Kota yang bersumber dari bagian dana perimbangan keuangan Pusat dan Daerah yang diterima oleh Kabupaten/Kota untuk Desa paling sedikit 10\% (sepuluh perseratus). Tujuan Alokasi Dana Desa adalah:

a. Menanggulangi kemiskinan dan mengurangi kesenjangan;

b. Meningkatkan perencanaan dan penganggaran pembangunan di tingkat Desa dan pemberdayaan masyarakat;

c. Meningkatkan pembangunan infrastruktur perdesaan;

d. Meningkatkan pengalaman nilainilai keagamaan, sosial budaya 
dalam rangka mewujudkan peningkatan sosial;

e. Meningkatkan ketentraman dan ketertiban masyarakat;

f. Meningkatkan pelayanan pada masyarakat Desa dalam rangka pengembangan kegiatan sosial dan ekonomi masyarakat;

g. Mendorong peningkatan keswadayaan dan gotong royong masyarakat;

h. Meningkatkan pendapatan Desa dan masyarakat Desa melalui Badan Usaha Milik Desa (BUMDesa). ${ }^{22}$

Alokasi Dana Desa dalam APBD Kabupaten/kota dianggarkan pada bagian Pemerintahan Desa. Pemerintah Desa membuka rekening pada Bank yang ditunjuk berdasarkan Keputusan Kepala Desa. Kepala Desa mengajukan permohonan penyaluran alokasi dana desa kepada Bupati c.q Kepala Bagian Pemerintahan Desa Sekretariat Daerah Kabupaten/Kota melalui Camat setelah dilakukan verifikasi oleh tim pendamping kecamatan. Bagian Pemerintahan Desa kepada Sekretariat Daerah Kabupaten/Kota akan meneruskan berkas permohonan berikut lampirannya kepada Kepala Bagian Keuangan Sekretariat Daerah Kabupaten/Kota atau Kepala Badan Pengelolaan Keuangan Daerah (BPKD) atau Kepala Badan Pengelola Keuangan dan Kekayaan Aset Daerah (BPKKAD). Kepala Bagian Keuangan Sekretariat
Daerah atau Kepala BPKD atau Kepala BPKKAD akan menyalurkan Alokasi Dana Desa langsung dari kas Daerah ke rekening Desa. Mekanisme pencairan Alokasi Dana Desa dalam Anggaran Pendapatan Belanja dan Desa dilakukan secara bertahap atau disesuaikan dengan kemampuan dan kondisi Daerah Kabupaten/Kota.

Pelaksanaan kegiatan-kegiatan yang pembiayaannya bersumber dari Alokasi Dana Desa dalam Anggaran Pendapatan dan Belanja Desa sepenuhnya dilaksanakan oleh tim pelaksana Desa dengan mengacu kepada Peraturan Bupati/Wali Kota. Penggunaan anggaran Alokasi Dana Desa adalah sebesar 30\% (tiga puluh perseratus) untuk belanja aparatur dan operasional Pemerintah Desa, sebesar $70 \%$ (tujuh puluh perseratus) untuk biaya pemberdayaan masyarakat. Belanja pemberdayaan masyarakat digunakan untuk:

a. Biaya perbaikan sarana publik dalam skala kecil;

b. Penyertaan modal usaha masyarakat melalui Badan Usaha Milik Desa (BUMDesa);

c. Biaya untuk pengadaan ketahanan pangan;

d. Perbaikan lingkungan dan pemukiman;

e. Teknologi tepat guna;

f. Perbaikan kesehatan dan pendidikan;

g. Pengembangan sosial budaya;

\footnotetext{
${ }^{22}$ Hanif Nurcholis, op.cit., hlm. 88-89.
} 
h. Kegiatan lain yang dianggap penting. $^{23}$

Pertanggungjawaban Alokasi Dana

Desa terintegrasi dengan pertanggungjawaban Anggaran Pendapatan dan Belanja Desa (APBDes), sehingga bentuk pertanggungjawabannya adalah pertanggungjawaban Anggaran Pendapatan dan Belanja Desa. Bentuk pelaporan atas kegiatan-kegaiatan dalam Anggaran Pendapatan dan Belanja Desa yang dibiayai dari Alokasi Dana Desa adalah, sebagai berikut:

a. Laporan berkala, artinya laporan mengenai pelaksanaan penggunaan dana Alokasi Dana Desa dibuat secara rutin setiap bulan. Adapun yang dimuat dalam laporan berkala adalah realisasi penerimaan Alokasi Dana Desa dan realisasi belanja Alokasi Dana Desa;

b. Laporan akhir penggunaan Alokasi Dana Desa, yang mencakup perkembangan pelaksanaan dan penyerapan dana, masalah yang dihadapi, dan rekomendasi penyelesaian hasil akhir penggunaan Alokasi Dana Desa.

Penyampaian laporan dilaksanakan melalui jalur struktural, yaitu dari tim pelaksana tingkat Desa dan diketahui Kepala Desa ke tim pendamping tingkat Kecamatan secara bertahap. Tim pendamping tingkat Kecamatan membuat laporan/rekapan dari seluruh laporan tingkat Desa di wilayah Kecamatan dan secara bertahap melaporkannya kepada Bupati cq. Tim fasilitasi tingkat Kabupaten/Kota. Pembiayaan dalam rangka pelaksanaan tugas pendampingan tim pendamping dibebankan pada Anggaran Pendapatan Belanja Daerah (APBD) Kabupaten/Kota di luar dana Alokasi Dana Desa.

Pemerintah Provinsi wajib mengoordinir pemberian dan penyaluran Alokasi Dana Desa dari Kabupaten/Kota kepada Desa. Pemerintah Kabupaten/Kota dan Camat wajib membina dan mengawasi pelaksanaan pengelolaan keuangan Desa. Pembinaan dan pengawasan Pemerintah Kabupaten/Kota meliputi: ${ }^{24}$

a. Memberikan pedoman dan bimbingan pelaksanaan Alokasi Dana Desa;

b. Memberikan bimbingan, pelatihan dan penyelenggaraan keuangan Desa yang mencakup perencanaan dan penyusunan Anggaran Pendapatan dan Belanja Desa, pelaksanaan dan pertanggungjawaban Anggaran Pendapatan dan Belanja Desa;

c. Membina dan mengawasi pengelolaan keuangan Desa dan pendayagunaan aset Desa;

d. Memberikan pedoman dan bimbingan pelaksanaan administrasi keuangan Desa.

Pembinaan dan pengawasan Camat meliputi: 

a. Memfasilitasi
administrasi keuangan Desa;
b. Memfasilitasi pengelolaan keuangan Desa dan pendayagunaan aset Desa;
c. Memfasilitasi pelaksanaan Alokasi Dana Desa;
d. Memfasilitasi penyelenggaraan keuangan Desa yang mencakup perencanaan, dan penyusunan Anggaran Pendapatan dan Belanja Desa.

Pemerintahan Desa diselenggarakan oleh Pemerintah Desa. ${ }^{25}$ Pemerintah Desa adalah Kepala Desa atau yang disebut dengan nama lain dan yang dibantu oleh Perangkat Desa atau yang disebut dengan nama lain. $^{26}$ Kepala Desa bertugas menyelenggarakan Pemerintahan Desa, melaksanakan pembangunan Desa, pembinaan kemasyarakatan Desa, dan pemberdayaan masyarakat Desa. ${ }^{27}$ Kepala Desa dalam melaksanakan tugasnya, berwenang: ${ }^{28}$
a. Memimpin Pemerintahan Desa;
penyelenggaraan
b. Mengangkat dan memberhentikan Perangkat Desa;
c. Memegang kekuasaan pengelolaan keuangan dan aset Desa;
d. Menetapkan Peraturan Desa;
e. Menetapkan Anggaran Pendapatan dan Belanja Desa;
f. Membina kehidupan masyarakat Desa;
g. Membina ketentraman dan ketertiban masyarakat Desa;

\footnotetext{
${ }^{25}$ Pasal 23 UU Nomor 6 Tahun 2014 tentang Desa

${ }^{26}$ Pasal 25 UU Nomor 6 Tahun 2014 tentang Desa.

${ }^{27}$ Pasal 26 ayat (1) UU Nomor 6 Tahun 2014 tentang Desa.

${ }^{28}$ Pasal 26 ayat (2) UU Nomor 6 Tahun 2014 tentang
}

h. Membina dan meningkatkan perekonomian Desa serta mengintegrasikannya agar mencapai perekonomian skala produktif untuk sebesar-besarnya kemakmuran masyarakat Desa;

i. Mengembangkan sumber pendapatan Desa;

j. Mengusulkan dan menerima pelimpahan sebagian kekayaan negara guna meningkatkan kesejahteraan masyarakat Desa;

k. Mengembangkan kehidupan sosial budaya masyarakat Desa;

1. Memanfaatkan teknologi tepat guna;

m. Mengoordinasikan Pembangunan Desa secara partisipatif;

n. Mewakili Desa di dalam dan luar pengadilan atau menunjuk kuasa hukum untuk mewakilinya sesuai dengan ketentuan peraturan perundang-undangan ; dan

o. Melaksanakan wewenang lain yang sesuai dengan ketentuan peraturan perundang-undangan.

Kepala Desa dalam melaksanakan tugasnya, Kepala Desa berhak:

a. Mengusulkan struktur organisasi dan tata kerja Pemerintah Desa;

b. Mengajukan rancangan dan menetapkan Peraturan Desa;

c. Menerima penghasilan tetap setiap bulan, tunjangan, dan penerimaan lainnya yang sah, serta mendapat jaminan kesehatan;

d. Mendapatkan perlindungan hukum atas kebijakan yang dilaksanakan; dan

e. Memberikan mandate pelaksanaan tugas dan kewajiban lainnya kepada perangkat Desa.

Kepala Desa mempunyai kewajiban: ${ }^{29}$
a. Memegang teguh dan mengamalkan Pancasila, 
melaksanakan Undang-Undang Dasar Negara Republik Indonesia Tahun 1945, serta mempertahankan dan memelihara keutuhan Negara Kesatuan Republik Indonesia, dan Bhineka Tunggal Ika;

b. Meningkatkan kesejahteraan masyarakat Desa;

c. Memelihara ketentraman dan ketertiban masyarakat Desa;

d. Menaati dan menegakkan seluruh peraturan perundang-undangan;

e. Melaksanakan kehidupan demokrasi dan berkeadilan gender;

f. Melaksanakan prinsip tata Pemerintahan Desa yang akuntabel, transparan, professional, efektif dan efisien, bersih, serta bebas dari kolusi, korupsi, dan nepotisme;

g. Menjalin kerja sama dan koordinasi dengan seluruh pemangku kepentingan di Desa;

h. Menyelenggarakan administrasi Pemerintahan Desa yang baik;

i. Mengelola Keuangan dan Aset Desa;

j. Melaksanakan urusan pemerintahan yang menjadi kewenangan Desa;

k. Menyelesaikan perselisihan masyarakat di Desa;

1. Mengembangkan perekonomian masyarakat Desa;

m. Membina dan melestarikan nilai sosial budaya masyarakat Desa;

n. Memberdayakan masyarakat dan lembaga kemasyarakatan di Desa;

o. Mengembangkan potensi sumber daya alam dan melestarikan lingkungan hidup; dan

p. Memberikan informasi kepada masyarakat Desa.

Kepala Desa dalam melaksanakan tugas, kewenangan, hak, dan kewajibannya, Kepala Desa wajib: (a) menyampaikan laporan penyelenggaraan Pemerintahan Desa setiap akhir tahun anggaran kepada Bupati/Walikota; (b) menyampaikan laporan penyelenggaraan Pemerintahan Desa pada akhir masa jabatan kepada Bupati/Walikota; (c) memberikan laporan keterangan penyelenggaraan pemerintahan secara tertulis kepada Badan Permusyawaratan Desa setiap akhir tahun anggaran; dan (d) memberikan dan/atau menyebarkan informasi penyelenggaraan pemerintahan secara tertulis kepada masyarakat Desa setiap akhir tahun anggaran. ${ }^{30}$

Kepala Desa yang tidak melaksanakan kewajiban sebagaimana dimaksud dalam Pasal 26 ayat (4) dan Pasal 27 UU Nomor 6 Tahun 2014 tentang Desa, maka Kepala Desa dikenai sanksi administratif berupa teguran lisan dan/atau teguran tertulis. ${ }^{31}$ Apabila sanksi administratif tidak dilaksanakan, dilakukan tindakan pemberhentian sementara dan dapat dilanjutkan dengan pemberhentian. ${ }^{32}$

Kepala Desa dilarang: (a) merugikan kepentingan umum; (b) membuat keputusan yang menguntungkan diri sendiri, anggota keluarga, pihak lain, dan/atau golongan tertentu; menyalahgunakan wewenang, tugas, hak, dan/atau kewajibannya; (d) melakukan tindakan diskriminatif terhadap warga

\footnotetext{
${ }^{30}$ Pasal 27 UU Nomor 6 Tahun 2014 tentang Desa

${ }^{31}$ Pasal 28 ayat (1) UU Nomor 6 Tahun 2014 tentang

Desa. 
dan/atau golongan masyarakat tertentu; (e) melakukan tindakan meresahkan sekelompok masyarakat Desa; melakukan kolusi, korupsi, dan nepotisme, menerima uang, barang, dan/atau jasa dari pihak lain yang dapat memengaruhi keputusan atau tindakan yang akan dilakukannya; (g) menjadi pengurus partai politik; (h) menjadi anggota dan/atau pengurus organisasi terlarang; merangkap jabatan sebagai ketua dan/atau anggota Badan Permusyawaratan Desa, anggota Dewan Perwakilan Rakyat Republik Indonesia, Dewan Perwakilan Daerah Republik Indonesia, Dewan Perwakilan Rakyat Daerah Provinsi atau Dewan Perwakilan Rakyat Daerah Kabupaten/Kota, dan jabatan lain yang ditentukan dalam peraturan perundangundangan; (j) ikut serta dan/atau terlibat dalam kampanye pemilihan umum dan/atau pemilihan kepala daerah; (k) melanggar sumpah/janji jabatan; dan (l) meninggalkan tugas selama 30 (tiga puluh) hari kerja berturut-turut tanpa alas an yang jelas dan tidak dapat dipertanggungjawabkan. ${ }^{33}$

Perangkat Desa terdiri atas: (a) Sekretariat Desa; (b) Pelaksana kewilayahan; dan (c) Pelaksana teknis. ${ }^{34}$ Perangkat Desa sebagaimana dimaksud

\footnotetext{
${ }^{33}$ Pasal 29 UU Nomor 6 Tahun 2014 tentang Desa.
}

${ }^{34}$ Pasal 48 UU Nomor 6 Tahun 2014 tentang Desa.

dalam Pasal 48 UU Nomor 6 Tahun 2014 tentang Desa, bertugas membantu Kepala Desa dalam melaksanakan tugas dan wewenangnya. ${ }^{35}$ Perangkat Desa diangkat oleh Kepala Desa setelah dikonsultasikan dengan Camat atas nama Bupati/Walikota. ${ }^{36}$ Perangkat Desa dalam melaksnakan tugas dan wewenangnya serta bertanggungjawab kepada Kepala Desa. ${ }^{37}$

Perangkat Desa dilarang:

merugikan kepentingan umum; (b) membuat keputusan yang menguntungkan diri sendiri, anggota keluarga, pihak lain, dan/atau golongan tertentu; menyalahgunakan wewenang, tugas, hak, dan/atau kewajibannya; (d) melakukan tindakan diskriminatif terhadap warga dan/atau golongan masyarakat tertentu; (e) melakukan tindakan meresahkan sekelompok masyarakat Desa; melakukan kolusi, korupsi, dan nepotisme, menerima uang, barang, dan/atau jasa dari pihak lain yang dapat memengaruhi keputusan atau tindakan yang akan dilakukannya; (g) menjadi pengurus partai politik; (h) menjadi anggota dan/atau pengurus organisasi terlarang; merangkap jabatan sebagai ketua dan/atau anggota Badan Permusyawaratan Desa, anggota Dewan Perwakilan Rakyat

\begin{tabular}{|c|c|}
\hline & ${ }^{35}$ Pasal 49 ayat (1) UU Nomor 6 Tahun 2014 tentang \\
\hline sa & ${ }^{36}$ Pasal 49 ayat (2) UU nomor 6 Tahun 2014 tentang \\
\hline Desa. & ${ }^{37}$ Pasal 49 ayat (3) UU Nomor 6 Tahun 2014 tentang \\
\hline
\end{tabular}


Republik Indonesia, Dewan Perwakilan Daerah Republik Indonesia, Dewan Perwakilan Rakyat Daerah Provinsi atau dewan Perwakilan Rakyat Daerah Kabupaten/Kota, dan jabatan lain yang ditentukan dalam peraturan perundangundangan; (j) ikut serta dan/atau terlibat dalam kampanye pemilihan umum dan/atau pemilihan kepala daerah; (k) melanggar sumpah/janji jabatan; dan (1) meninggalkan tugas selama 60 (enam puluh) hari kerja berturut-turut tapa alasan yang jelas dan tidak dapat dipertanggungjawabkan. ${ }^{38}$

Penyalahgunaan Alokasi Dana Desa oleh Kepala Desa disebabkan tidak sesuai dengan Rencana Anggaran Biaya (RAB), sehingga Kepala Desa menyalahgunakan wewenangnya atau diduga melakukan korupsi atas tugasnya dalam mengelola keuangan Desa.

Penyalahgunaan Alokasi Dana Desa terhadap Kepala Desa dalam Pemerintahan Desa juga dapat terjadi dikarenakan oleh perilaku dan gaya hidup Kepala Desa menjadi salah satu faktor terjadinya korupsi penyelewengan Alokasi Dana Desa.

Contohnya penggunaan Alokasi Dana Desa menjadi salah satu sumber korupsi. Hal ini terbukti pada saat Komisi Pemberantasan Korupsi (KPK) melakukan

\footnotetext{
${ }^{38}$ Pasal 51 UU Nomor 6 Tahun 2014 tentang Desa.
}

Operasi Tangkap Tangan (OTT) karena Bupati Pamekasan menyuap Kejaksaan Negeri Pamekasan, Jawa Timur. Penyuapan tersebut diberikan untuk menghentikan pengusutan yang dilakukan Kejaksaan Negeri dalam korupsi proyek infrastruktur senilai Rp 100.000.000,00. yang menggunakan dana Desa. ${ }^{39}$

Kemudian Kepala Desa di Labuhan Tangga, Kecamatan Bangko, Kabupaten Rokan Hilir, Provinsi Riau,korupsi dana Desa sebesar Rp 399.000.000,00. dalam Anggaran Pendapatan dan Belanja Daerah Rokan Hilir tahun 2015. Dana Desa yang semestinya diperuntukkan pembangunan Desa, dikorupsi oleh Kepala Desa, tidak satupun proyek fisik yang dibangun di Desa tersebut. ${ }^{40}$

Ada empat Kepala Desa di Kabupaten Karawang yang terjerat kasus korupsi dikarenakan penyelewengan Alokasi Dana Desa, diantaranya Kepala Desa Kertajaya Kecamatan Jayakerta, Kepala Desa Malangsari Kecamatan Pedes, Kepala Desa Pasirtanjung Kecamatan Lemahabang, dan Kepala Desa Cilewo Kecamatan Telagasari. $^{41}$

Menurut data Kepolisian Republik Indonesia dari tahun 2012 - 2017 ada 214 (dua ratus empat belas) kasus penyelewengan dana Desa, total kerugian

\footnotetext{
${ }^{39}$ Kompas, 21 Agustus 2017

${ }^{40}$ Kompas, 18 Juli 2017

${ }^{41}$ Media Indonesia, 25 Oktober 2017
} 
Negara mencapai Rp 46.000.000.000,00. Sejumlah modus penyelewengan dana Desa, diantaranya: menggelapkan dan memotong anggaran proyek, pengadaan proyek fikif dan penggelembungan nilai proyek yang berlebih. ${ }^{42}$

Apabila terjadi penyalahgunaan Alokasi Dana Desa yang dilakukan oleh Kepala Desa dengan Perangkat Desa (Sekretariat Desa, Pelaksana Kewilayahan, dan Pelaksana Teknis) yang ditunjuk. Kepala Desa melanggar Pasal 29 huruf c Undang-Undang Nomor 6 Tahun 2014 tentang Desa: Kepala Desa dilarang menyalahgunakan wewenang, tugas, hak, dan/atau kewajibannya. Begitupun sama dengan Perangkat Desa melanggar Pasal 51 huruf c undang-Undang Nomor 6 Tahun 2014 tentang Desa: Perangkat Desa dilarang menyalahgunakan wewenang, tugas, hak, dan/atau kewajibannya.

Maka Kepala Desa yang melanggar larangan sebagaimana dimaksud dalam Pasal 29 UU Nomor 6 Tahun 2014 tentang Desa, dikenai sanksi administratif berupa teguran lisan dan/atau teguran tertulis. ${ }^{43}$ Apabila sanksi administratif sebagaimana dimaksud Pasal 30 ayat (1) tidak dilaksanakan, dilakukan tindakan pemberhentian sementara dan dapat

${ }^{43}$ Pasal 30 ayat (1) UU Nomor 6 Tahun 2014 tentang dilanjutkan dengan pemberhentian. ${ }^{44}$

Perangkat Desa yang melanggar larangan sebagaimana dimaksud dalam Pasal 51 UU Nomor 6 Tahun 2014 tentang Desa, dikenai sanksi administratif berupa teguran lisan dan/atau teguran tertulis. ${ }^{45}$ Apabila sanksi administratif tidak dilaksanakan, dilakukan tindakan pemberhentian sementara dan dapat dilanjutkan dengan pemberhentian. ${ }^{46}$

Jadi, pada hakikatnya, dalam menjalankan tugasnya Kepala Desa dan Perangkat Desa itu dilarang untuk menyalahgunakan wewenangnya. Kepala Desa dan Perangkat desa yang melanggar konsekuensinya dapat dikenakan sanksi administratif.

Kemudian selain itu, perbuatan tersebut dapat juga dikategorikan sebagai tindak pidana korupsi, dan aturan yang dipakai adalah Undang-Undang Nomor 31 Tahun 1999 tentang Pemberantasan Tindak Pidana Korupsi sebagaimana telah diubah dengan Undang-Undang Nomor 20 Tahun 2001 tentang Perubahan Atas UndangUndang Nomor 31 Tahun 1999 tentang Pemberantasan Tindak Pidana Korupsi. Konsekuensinya, ada ancaman pidana bagi orang yang menyalahgunakan wewenangnya yang berakibat dapat

\footnotetext{
${ }^{44}$ Pasal 30 ayat (2) UU Nomor 6 Tahun 2014 tentang Desa

${ }^{45}$ Pasal 52 ayat (1) UU Nomor 6 Tahun 2014 tentang

Desa. Desa.
} 
merugikan keuangan negara.

Pasal 3 Undang-Undang Nomor 20 Tahun 2001 tentang Perubahan Atas Undang-Undang Nomor 31 Tahun 1999 tentang Pemberantasan Tindak Pidana Korupsi, menyatakan bahwa:

"Setiap orang yang dengan tujuan menguntungkan diri sendiri atau orang lain atau suatu korporasi, menyalahgunakan kewenangan, kesempatan atau sarana yang ada padanya karena jabatan atau kedudukan yang dapat merugikan keuangan negara, dipidana dengan pidana penjara seumur hidup atau pidana penjara paling singkat 1 (satu) tahun dan paling lama 20 (dua puluh) tahun dan atau denda paling sedikit lima puluh juta rupiah dan paling banyak satu miliar rupiah".

Selanjutnya cara melaporkan adanya tindak dugaan penyelewengan Alokasi Dana Desa, masyarakat dapat mengambil langkah-langkah sebagai berikut:

1) Masyarakat dapat membuat pelaporan atau pengaduan kepada Badan Permusyawaratan Desa (BPD) setempat, serta kepada Pemerintah Supra Desa (Kecamatan), mengenai obyek kegiatan serta perkiraan nilai kerugian yang diselewengkan;

2) Pelaporan ataupun pengaduan tersebut, perlu disertai dengan penjelasan konkrit mengenai obyek kegiatan yang menjadi dugaan tindak penyelewengan. Hal ini untuk menghindari anggapan bahwa laporan yang disampaikan itu hanya didasarkan atas informasi yang tidak utuh, atau hanya praduga-praduga yang tidak berdasar. Oleh karena itu, disarankan kepada masyarakat Desa, dalam menjalankan fungsi pengawasan pembangunan di wilayahnya, dan juga perlu mengedepankan upaya-upaya dialogis, dengan meminta penjelasan atau konfirmasi mengenai indikasi terjadinya korupsi kepada pihak yang dicurigai terlibat melakukan tindakan menyalahgunakan wewenang tersebut;

3) Apabila tidak ada tindak lanjut dari kedua lembaga (BPD dan Kecamatan) atas pelaporan yang telah dilakukan, maka masyarakat dapat menyampaikan dugaan penyelewengan Alokasi Dana Desa tersebut kepada Pemerintah Kabupaten, dalam hal ini adalah Bupati cq. Satuan Kerja Perangkat Daerah (SKPD) yang membidangi pembinaan penyelenggaraan Pemerintahan Desa, serta Inspektorat Daerah Kabupaten, atau apabila masyarakat mempunyai bukti yang kuat dan dapat dipertanggung-jawabkan di hadapan hukum atas dugaan 
penyelewengan Alokasi Dana Desa

(korupsi), maka masyarakat berhak melaporkan oknum Kepala Desa dan Perangkat Desa tersebut kepada pihak aparat penegak hukum atas proses tindak lanjut;

4) Pemerintah sangat perhatian terhadap praktik-praktik tindakan korupsi dan pungutan liar, karena hal itu dapat berdampak pada kerusakan nilai-nilai sosial dan kepercayaan publik kepada Pemerintah.

Kemudian konsekuensinya, Kepala Desa yang terbukti telah melakukan tindakan korupsi tersebut dapat diberhentikan oleh Bupati/Walikota, ${ }^{47}$ dan ketentuan lebih lanjut mengenai pemberhentian Kepala Desa diatur dalam Peraturan Pemerintah. ${ }^{48}$

Pasal 54 ayat (3) dan ayat (4) Peraturan Pemerintah Nomor 47 Tahun 2015 tentang Perubahan Peraturan Pemerintah Nomor 43 Tahun 2014 tentang Peraturan Pelaksanaan Undang-undang Nomor 6 Tahun 2014 tentang Desa, menyebutkan bahwa: "Apabila Kepala Desa berhenti (meninggal dunia, permintaan sendiri atau diberhentikan), Badan Permusyawaratan Desa melaporkan kepada Bupati/Walikota

\footnotetext{
${ }^{47}$ Pasal 40 ayat (3) Undang-Undang Nomor 6 Tahun 2014 tentang Desa.

${ }^{48}$ Pasal 40 ayat (4) Undang-Undang Nomor 6 Tahun 2014 tentang Desa.
}

melalui Camat atau sebutan lain". ${ }^{49}$ "Pemberhentian Kepala Desa sebagaimana pada ayat (3) ditetapkan dengan Keputusan Bupati". 50

Oleh karena itu, supaya setiap tindakan atau indikasi korupsi dapat ditangani dengan optimal, masyarakat dapat membantu dengan memberikan informasi serta diperkuat dengan bukti-bukti yang cukup akan terjadinya tindakan korupsi, dan apabila berkaitan dengan penyalahgunaan Keuangan Desa, dalam hal ini adalah penyalahgunaan Alokasi Dana Desa, maka perbuatan tersebut dikategorikan korupsi.

engan tolak ukur bahwasanya tindak pidana korupsi bersifat tindak pidana yang luar biasa (extra ordinary crimes) karena bersifat sistemik, endemik yang berdampak sangat luas (systematic dan widespread) yang tidak hanya merugikan keuangan negara tetapi juga melanggar hak sosial dan ekonomi masyarakat luas sehingga penindakannya perlu upaya comprehensive extra ordinary measures sehingga banyak peraturan, lembaga dan komisi yang di bentuk oleh pemerintah untuk menanggulanginya. ${ }^{51}$

\footnotetext{
${ }^{49}$ Pasal 54 ayat (3) PP Nomor 47 Tahun 2015 tentang Perubahan Atas PP Nomor 43 Tahun 2014 tentang Pelaksanaan Undang-Undang Nomor 6 Tahun 2014 tentang Desa.

${ }^{50}$ Pasal 54 ayat (4) PP Nomor 47 Tahun 2015 tentang Perubahan Atas PP Nomor 43 Tahun 2014 tentang Pelaksanaan Undang-Undang Nomor 6 Tahun 2014 tentang Desa.

51 Ifrani, Tindak Pidana Korupsi Sebagai Tindak Pidana Luar Biasa, Jurnal Al Adl Volume IX Nomor 3 Desember 2013, hlm. 321.
} 


\section{PENUTUP}

Penyalahgunaan Alokasi Dana Desa oleh Kepala Desa ini dapat dikategorikan sebagai tindak pidana korupsi. Kepala Desa yang melakukan tindak pidana korupsi tersebut dan terbukti dipersidangan secara sah dan meyakinkan divonis oleh Majelis Hakim bersalah, maka konsekuensinya adalah Kepala Desa tersebut dapat diberhentikan dengan aturan Undang-Undang Nomor 6 Tahun 2014 tentang Desa dan Peraturan Pemerintah Nomor 47 Tahun 2015 tentang Perubahan Atas Peraturan Pemerintah Nomor 43 Tahun 2014 tentang Peraturan Pelaksanaan Undang-undang Nomor 6 Tahun 2014 tentang Desa. Kepala Desa harus berhatihati (tabayyun) dan tidak ceroboh dalam mengelola Alokasi Dana Desa, dengan cara membaca dan memahami peraturan perundang-undangan yang berhubungan dengan Pemerintahan Desa, khususnya peraturan perundang-undangan tentang Alokasi Dana Desa. Kemudian Kepala desa juga harus rajin mengikuti pelatihanpelatihan tentang pengelolaan Alokasi Dana Desa, supaya tidak terjadi penyalahgunaan wewenang, hak dan kewajiban.

\section{DAFTAR PUSTAKA}

Buku

Bagir Manan, 1993, Perjalanan Historis
Pasal 18 UUD 1945, UNSIKA, Karawang.

Hanif Nurcholis, 2011, Pertumbuhan \& Penyelenggaraan Pemerintahan Desa, Erlangga, Jakarta.

Hazairin, 1970, Demokrasi Pancasila, Tintamas, Jakarta.

Jimly Asshiddiqie, 2007, Pokok-Pokok Hukum Tata Negara Indonesia Pasca Reformasi, PT. Bhuana Ilmu Populer, Jakarta.

Mashuri Maschab, 2013, Politik Pemerintahan Desa di Indonesia, PolGov UGM, Yogyakarta.

Moh. Mahfud, 2010, Politik Hukum di Indonesia, Rajawali Pers, Jakarta.

Nata Irawan, 2017, Tata Kelola Pemerintahan Desa di Indonesia, Yayasan Pustaka Obor, Jakarta.

Ridwan, 2009, Hukum Administrasi di

Daerah, FH-UII Press, Yogyakarta.

Siswanto Sunarno, 2008, Hukum Pemerintahan Daerah di Indonesia, Sinar Grafika, Jakarta.

Soetarjo Kartohadikoesoemo, 1953, Desa, Universitas Gajah Mada, Yogyakarta.

\section{Jurnal}

Ifrani, Tindak Pidana Korupsi Sebagai Tindak Pidana Luar Biasa, Jurnal Al Adl Volume IX Nomor 3 Desember 2013

\section{Peraturan Perundang-Undangan}

Undang-Undang Dasar 1945

Undang-Undang nomor 20 Tahun 2001 tentang Perubahan Atas UndangUndang Nomor 31 Tahun 1999 tentang Pemberantasan Tindak Pidana Korupsi.

Undang-Undang Nomor 33 Tahun 2004 tentang Perimbangan Keuangan Pemerintah dengan Pemerintahan Daerah.

Undang-Undang Nomor 5 Tahun 1979 
tentang Pemerintahan Desa.

Undang-Undang Nomor 6 Tahun 2014 tentang Desa.

Peraturan Pemerintah Nomor 47 Tahun 2015 tentang Perubahan Atas Peraturan Pemerintah Nomor 43 Tahun 2014 tentang Pelaksanaan Undang-Undang Nomor 6 Tahun 2014 tentang Desa.

Peraturan Pemerintah Nomor 8 Tahun 2016 tentang Perubahan Kedua Atas Peraturan Pemerintah Nomor 60 Tahun 2014 tentang Dana Desa yang Bersumber dari Anggaran Pendapatan dan Belanja Negara. 